\title{
Analisis Keragaman Genetik Karakter Morfologi Populasi M2 Cabai Hasil Iradiasi Sinar Gamma
}

\section{Genetic Analysis of Chili Pepper M2 Population from Gamma Irradiation Treatment Based on Morphological Characters}

\author{
Kristianto Nugroho $^{1,2}$, Trikoesoemaningtyas ${ }^{3}$, Muhamad Syukur ${ }^{3 *}$, dan Puji Lestari ${ }^{4}$ \\ 'Program Studi Pemuliaan dan Bioteknologi Tanaman, Sekolah Pascasarjana, Institut Pertanian Bogor \\ ${ }^{2}$ Balai Besar Penelitian dan Pengembangan Bioteknologi dan Sumberdaya Genetik Pertanian \\ Jl. Tentara Pelajar 3A, Cimanggu Bogor 16111, Indonesia \\ ${ }^{3}$ Departemen Agronomi dan Hortikultura, Fakultas Pertanian, Institut Pertanian Bogor \\ (IPB University), Jl. Meranti, Kampus IPB Darmaga, Bogor 16680, Indonesia \\ ${ }^{4}$ Balai Besar Penelitian Tanaman Padi, Jl. Raya 9 Sukamandi, Subang 41256, Indonesia
}

Diterima 22 November 2021/Disetujui 23 Desember 2021

\begin{abstract}
Mutation is a useful technique that could be used to increase genetic variability of chili as a basis for developing new improved varieties. The aim of this study was to analyze the genetic variability of M2 population derived from gamma irradiation based on morphological characters. The analysis was conducted through estimation of genetic variability, broadsense heritability, and also path analysis to see which characters have a direct and indirect effect on the yield. As many as 350 M2 plants were evaluated for their morphological characters at the ICABIOGRAD experimental field in Bogor from August 2020 to January 2021. The results showed that harvest period and canopy width had a broad genetic variability in M2 population. Several quantitative characters such as fruit length, fruit diameter, weight per fruit, leaf length, leaf width, and canopy width showed high broad-sense heritability values. Path analysis showed that there were two characters namely stem diameter and canopy width with the highest direct effect on the yield.
\end{abstract}

Keywords: correlation, genetic variance, heritability, induced mutation, path analysis

\section{ABSTRAK}

Mutasi merupakan teknik untuk meningkatkan keragaman genetik sebagai modal dasar perakitan varietas unggul. Tujuan penelitian ini adalah untuk menganalisis keragaman genetik populasi M2 cabai hasil iradiasi sinar gamma berdasarkan karakter morfologi. Analisis keragaman genetik dilakukan melalui pendugaan ragam genetik, heritabilitas arti luas, serta sidik lintas karakter-karakter yang berpengaruh langsung maupun tidak langsung terhadap hasil. Sebanyak 350 tanaman M2 dievaluasi karakter morfologinya di Kebun Percobaan BB Biogen Bogor pada bulan Agustus 2020 hingga Januari 2021. Hasil analisis menunjukkan nilai keragaman genetik yang luas pada populasi M2 diperoleh pada karakter umur panen dan lebar tajuk. Nilai heritabilitas arti luas yang tinggi terdapat pada karakter panjang buah, diameter buah, bobot per buah, panjang daun, lebar daun, dan lebar tajuk. Sementara itu sidik lintas menunjukkan terdapat dua karakter yang memiliki nilai pengaruh langsung yang besar terhadap hasil yaitu diameter batang dan lebar tajuk.

Kata kunci: heritabilitas, induksi mutasi, korelasi, ragam genetik, sidik lintas

\section{PENDAHULUAN}

Cabai merupakan komoditas hortikultura bernilai ekonomi tinggi. Tingkat konsumsi cabai sangat dipengaruhi oleh preferensi konsumen yang menilai produk berdasarkan penampilan luar, kesegaran, rasa, dan aroma (Adiyoga dan

\footnotetext{
* Penulis untuk korespondensi. e-mail: muhsyukur@apps.ipb. ac.id
}

Nurmalinda, 2013). Menurut Kusandriani (1996), konsumen lebih menyukai buah cabai berwarna merah dengan ukuran sedang serta permukaan kulit yang rata dan halus. Sementara itu masyarakat di Sumatera Barat umumnya lebih menyukai buah cabai dengan permukaan kulit yang bergelombang (keriting) karena cabai keriting memiliki rasa yang lebih pedas (Ekaputra et al., 2018). Varietas Lingga merupakan salah satu varietas unggul cabai yang telah dilepas oleh Badan Litbang Pertanian dengan potensi hasil 
mencapai 16 ton ha $\mathrm{ha}^{-1}$ (Balitbangtan, 2019). Upaya perbaikan varietas agar tidak hanya mampu berproduksi tinggi namun juga memiliki ukuran buah yang disukai konsumen dapat dilakukan melalui teknik induksi mutasi menggunakan sinar gamma. Teknik ini memiliki beberapa kelebihan antara lain mampu menghasilkan sifat baru yang tidak dimiliki tanaman induknya, dapat memperbaiki salah satu sifat dari suatu varietas tanpa mengubah sifat yang lain, dan dapat memisahkan adanya pautan gen (Harsanti dan Yulidar, 2019).

Beberapa penelitian menunjukkan bahwa aplikasi mutagen fisik mampu menyebabkan terjadinya perubahan pada morfologi buah cabai. Tahun 1992, Daskalov berhasil memperoleh mutan cabai yang memiliki buah berwarna oranye hasil iradiasi benih cabai kultivar Pazardzhishka kapia 794 menggunakan sinar X pada dosis 120 Gy (Tomlekova et al., 2021). Ojua et al. (2019) melaporkan bahwa penggunaan sinar gamma pada dosis 150 Gy pada cabai kultivar Nsukka Yellow menghasilkan buah dengan ukuran lebih panjang dibandingkan varietas asalnya.

Analisis keragaman genotipe mutan yang diperoleh dilakukan untuk mengetahui sejauh mana perubahan genetik dari varietas asalnya, memperoleh informasi karakter apa saja yang berbeda dari varietas asal, dan mengidentifikasi apakah perubahan yang terjadi memang disebabkan oleh perubahan genetik akibat mutasi dan bukan merupakan pengaruh dari lingkungan. Karakter morfologi dapat digunakan sebagai salah satu penanda penting untuk mengidentifikasi kemiripan dan keragaman pada tanaman (Sumilah et al., 2019). Karakter morfologi yang digunakan dalam kegiatan analisis keragaman genetik dapat meliputi karakter kualititatif maupun kuantitatif(Hartati dan Darsana, 2015; Herison et al., 2018). Kelebihan dari penggunaan karakter morfologi dalam menganalisis keragaman genetik tanaman yaitu bersifat relatif mudah dan murah untuk dilakukan (Indhirawati et al., 2015).

Tujuan dari penelitian ini adalah untuk menganalisis keragaman genetik populasi M2 cabai hasil iradiasi sinar gamma berdasarkan karakter morfologi. Analisis keragaman genetik dilakukan melalui pendugaan ragam genetik, heritabilitas arti luas, serta melakukan sidik lintas karakter-karakter yang berpengaruh langsung maupun tidak langsung terhadap hasil.

\section{BAHAN DAN METODE}

Kegiatan penelitian ini dilaksanakan pada bulan Agustus 2020 sampai dengan Januari 2021. Penelitian ini dilakukan di rumah kaca dan kebun percobaan BB Biogen, Cimanggu, Bogor. Materi genetik yang digunakan berupa populasi M2 cabai yang berasal dari hasil iradiasi varietas Lingga pada dosis 450 Gy. Kegiatan iradiasi dilakukan pada tahun 2019 di Pusat Aplikasi Isotop dan Radiasi (PAIR), Badan Tenaga Nuklir Nasional (BATAN), Jakarta.

Sebanyak 350 tanaman generasi M2 ditanam di bedengan yang berukuran $12 \mathrm{~m}$ x $1 \mathrm{~m}$ pada jarak tanam 50 $\mathrm{cm}$ dalam baris dan $60 \mathrm{~cm}$ antar baris. Setiap bedengan terdiri atas dua baris tanaman, setiap baris terdiri atas 25 tanaman, dengan jarak antar bedengan sebesar $60 \mathrm{~cm}$. Sebanyak 30 tanaman varietas asal yaitu varietas Lingga ditanam di setiap seratus nomor tanaman mutan. Sebanyak 13 karakter kuantitatif diamati pada penelitian ini yang meliputi panjang buah, diameter buah, tebal kulit buah, bobot per buah, bobot total buah per tanaman, tinggi tanaman, panjang batang, diameter batang, panjang daun, lebar daun, lebar tajuk, umur berbunga, dan umur panen. Pengamatan karakter kuantitatif pada populasi M2 dilakukan berdasarkan panduan deskripsi yang terdapat pada IPGRI (1995).

\section{Analisis Data}

Analisis data dilakukan menggunakan metode Singh dan Chaudary (1979) yang dimulai dengan menghitung nilai tengah setiap karakter kuantitatif pada populasi M2 dan Lingga. Nilai ragam genotipe, fenotipe, dan lingkungan diduga menggunakan nilai ragam populasi M2 dan Lingga dengan perhitungan seperti disajikan pada Tabel 1. Selanjutnya nilai tengah dari setiap karakter pada populasi M2 diuji menggunakan uji t terhadap nilai tengah populasi Lingga untuk melihat apakah terdapat perbedaan yang signifikan antara nilai tengah kedua populasi tersebut.

Nilai luas sempitnya keragaman genetik diduga dari nilai ragam genotipe dengan kriteria luas atau sempitnya keragaman genetik ditentukan berdasarkan kriteria Asghar dan Mehdi (2010) dengan ketentuan sebagai berikut: bila $\sigma^{2} \mathrm{~g}>2 \sigma_{\sigma \mathrm{g}}^{2}$ maka keragaman genetiknya luas, sedangkan bila $\sigma^{2} \mathrm{~g}<2 \sigma_{\sigma \mathrm{g}}^{2}$ maka keragaman genetiknya sempit.

Pendugaan heritabilitas arti luas dihitung berdasarkan rumus (Singh dan Chaudhary 1979):

$$
h^{2} b s=\frac{\sigma^{2} g}{\sigma^{2} p}
$$

dengan $\sigma^{2} \mathrm{~g}=$ ragam genotipe dan $\sigma^{2} \mathrm{p}=$ ragam fenotipe. Kriteria nilai heritabilitas ditentukan berdasarkan kriteria Stansfield (1991) yaitu kategori tinggi $\left(\mathrm{h}^{2} \geq 50 \%\right)$, sedang $\left(20 \% \leq \mathrm{h}^{2}<50 \%\right)$, dan rendah $\left(\mathrm{h}^{2}<20 \%\right)$. Nilai signifikansi dari heritabilitas arti luas dihitung berdasarkan standar deviasi heritabilitas basis plot menggunakan rumus (Lothrop et al., 1985):

$$
\text { Standar deviasi } h^{2}=\text { Standar deviasi }\left(\sigma^{2} g / \sigma^{2} p\right)
$$

Analisis hubungan tingkat keeratan antar karakter kuantitatif dilakukan menggunakan analisis korelasi

Tabel 1.Pendugaan ragam fenotipe, genotipe, dan lingkungan pada populasi M2 cabai hasil iradiasi sinar gamma

\begin{tabular}{ll}
\hline Nilai ragam & Penduga \\
\hline Ragam fenotipe $\left(\sigma^{2} \mathrm{p}\right)$ & Ragam populasi M2 $\left(\sigma^{2} \mathrm{M} 2\right)$ \\
Ragam lingkungan $\left(\sigma^{2} \mathrm{e}\right)$ & $\begin{array}{l}\text { Ragam populasi Lingga } \\
\left(\sigma^{2} \mathrm{M} 0\right)\end{array}$ \\
Ragam genotipe $\left(\sigma^{2} \mathrm{~g}\right)$ & $\begin{array}{l}\text { Selisih ragam populasi M2 } \\
\text { dengan ragam populasi Lingga } \\
\left(\sigma^{2} \mathrm{M} 2-\sigma^{2} \mathrm{M} 0\right)\end{array}$ \\
\hline
\end{tabular}


Pearson. Selanjutnya sidik lintas dilakukan menggunakan karakter bobot buah total per tanaman sebagai parameter produksi (variabel Y) dan karakter-karakter kuantittaif lainnya sebagai variabel X. Analisis ragam dan heritabilitas dilakukan menggunakan perangkat lunak Microsoft Excel, sedangkan analisis korelasi dan sidik lintas dilakukan menggunakan perangkat lunak $\mathrm{R}$ versi 4.0.2.

\section{HASIL DAN PEMBAHASAN}

\section{Pendugaan Ragam dan Heritabilitas Arti Luas Pada Populasi M2}

Hasilanalisiskeragamangenetik menunjukkan terdapat dua karakter kuantitatif morfologi buah yang berbeda nyata antara populasi M2 dibanding populasi Lingga, yaitu diameter buah dan bobot per buah (Tabel 2). Pada populasi M2 terlihat bahwa nilai tengah diameter buah dan bobot per buah lebih rendah dibanding nilai tengah populasi Lingga. Sementara itu karakter panjang buah, tebal kulit buah, dan bobot buah total per tanaman tidak menunjukkan perbedaan yang nyata antara populasi M2 dengan populasi Lingga.

Hasil pendugaan ragam pada penelitian ini menunjukkan bahwa terdapat dua karakter kuantitatif yaitu umur panen dan lebar tajuk yang menunjukkan keragaman genetik yang luas (Tabel 3). Menurut Andini et al. (2021) keragaman genetik yang luas diperlukan sebagai modal dasar dalam kegiatan pemuliaan tanaman khususnya dalam proses seleksi ke arah sifat-sifat yang lebih baik. Hasil penelitian Gaswanto et al. (2016) menunjukkan bahwa nilai $\mathrm{LD}_{50}$ tanaman cabai berada pada kisaran 422.64-629.68 Gy, tergantung varietas cabai yang digunakan. Perlakuan iradiasi pada dosis $\mathrm{LD}_{50}$ mampu meningkatkan keragaman pada tanaman dan karakter yang dituju (Nura et al., 2015).
Meskipun demikian menurut Sarsu et al. (2018) perlakuan iradiasi pada dosis rendah seringkali disarankan karena menghasilkan kerusakan kromosom dan efek negatif yang lebih kecil dibandingkan perlakuan pada dosis yang lebih tinggi. Sementara itu aplikasi iradiasi dengan dosis di atas $\mathrm{LD}_{50}$ dilakukan untuk memperoleh perubahan sifat yang bersifat ekstrim, seperti sifat kerdil atau steril (Warid et al., 2017).

Nilai heritabilitas arti luas yang tinggi terdapat pada enam karakter yaitu panjang buah, diameter buah, bobot per buah, panjang daun, lebar daun, lebar tajuk (Tabel 3). Sementara itu nilai heritabilitas arti luas yang rendah terdapat pada karakter tebal kulit buah, bobot buah total per tanaman, tinggi tanaman, panjang batang, dan umur panen (Tabel 3). Hasil yang sedikit berbeda diperoleh sebelumnya pada penelitian Sari et al. (2014) menggunakan sepuluh genotipe cabai besar di mana karakter panjang buah, diameter buah, tebal daging buah, bobot per buah, dan bobot buah total per tanaman memiliki kriteria heritabilitas arti luas yang tinggi. Nilai heritabilitas arti luas yang tergolong tinggi pada beberapa karakter kuantitatif yang diamati pada penelitian ini menunjukkan bahwa keragaman fenotipe yang terlihat pada karakter-karakter tersebut memang berasal dari keragaman genetik yang ada dan bukan berasal dari faktor lingkungan (Werdhiwati et al., 2020).

\section{Analisis Korelasi dan Sidik Lintas Karakter Kuantitatif Cabai}

Hasil analisis korelasi menunjukkan bahwa karakter panjang buah, diameter buah, tebal kulit buah, bobot per buah, panjang batang, diameter batang, lebar tajuk, panjang daun, dan lebar daun, menunjukkan korelasi yang positif terhadap bobot buah total per tanaman, sedangkan karakter

Tabel 2. Nilai tengah, simpangan baku, dan kisaran dari karakter kuantitatif populasi M2 cabai hasil iradiasi sinar gamma

\begin{tabular}{|c|c|c|c|c|}
\hline \multirow{2}{*}{ Karakter } & \multicolumn{2}{|c|}{ Populasi varietas Lingga } & \multicolumn{2}{|c|}{ Populasi M2 } \\
\hline & Rataan \pm SD & Kisaran & Rataan \pm SD & Kisaran \\
\hline Umur berbunga (hari) & $37.23 \pm 11.21$ & $17-57$ & $42.88 \pm 8.07$ & $19-58$ \\
\hline Panjang daun $(\mathrm{cm})$ & $6.3 \pm 0.41$ & $5-7$ & $6.25 \pm 0.67$ & $3-8$ \\
\hline Lebar daun $(\mathrm{cm})$ & $2.7 \pm 0.17$ & $2-3$ & $2.66 \pm 0.32$ & $1-4$ \\
\hline Tinggi tanaman $(\mathrm{cm})$ & $55.92 \pm 7.80$ & $35-69$ & $52.26 * \pm 8.00$ & $23-83$ \\
\hline Panjang batang (cm) & $20.93 \pm 2.87$ & $13-26$ & $19.52 \pm 3.08$ & $11-28$ \\
\hline Diameter batang (mm) & $11.84 \pm 2.11$ & $8-17$ & $12.39 \pm 2.51$ & $5-24$ \\
\hline Lebar tajuk $(\mathrm{cm})$ & $67.64 \pm 7.58$ & $51-85$ & $65.14 \pm 10.90$ & $22-89$ \\
\hline Umur panen (hari) & $87.05 \pm 8.03$ & $70-108$ & $89.09 \pm 8.53$ & $69-128$ \\
\hline Panjang buah (cm) & $12.59 \pm 0.58$ & $11-14$ & $11.99 \pm 1.37$ & $6-15$ \\
\hline Diameter buah (mm) & $12.68 \pm 0.60$ & $12-14$ & $12.10 * * \pm 1.09$ & $7-18$ \\
\hline Tebal kulit buah (mm) & $1.32 \pm 0.25$ & $1-2$ & $1.23 \pm 0.22$ & $1-2$ \\
\hline Bobot per buah $(\mathrm{g})$ & $9.05 \pm 0.77$ & 7-11 & $8.01 * * \pm 1.53$ & $3-11$ \\
\hline bobot buah total per tanaman $(\mathrm{g})$ & $423.27 \pm 165.54$ & $126-775$ & $357.62 \pm 145.71$ & $19-812$ \\
\hline
\end{tabular}

Keterangan: *hasil uji t menunjukkan perbedaan signifikan pada $\alpha=0.05, * *$ hasil uji t menunjukkan perbedaan signifikan pada $\alpha=0.01$, $\mathrm{SD}=$ simpangan baku 
Tabel 3. Nilai duga ragam genetik, heritabilitas arti luas, dan luas sempitnya keragaman genetik dari karakter kuantitatif populasi M2 cabai hasil iradiasi sinar gamma

\begin{tabular}{|c|c|c|c|c|c|}
\hline \multirow{2}{*}{ Karakter } & \multicolumn{5}{|c|}{ Komponen ragam } \\
\hline & $\sigma_{p}^{2}$ & $\sigma_{\mathrm{e}}^{2}$ & $\sigma_{g}^{2}$ & $2 \sigma \sigma_{g}^{2}$ & $\mathrm{~h}^{2} \mathrm{bs}(\%)$ \\
\hline Umur berbunga (hari) & 65.09 & 125.60 & $0.00^{\mathrm{S}}$ & 0.00 & $0.00^{\mathrm{R}}$ \\
\hline Panjang daun (cm) & 0.45 & 0.17 & $0.28^{\mathrm{S}}$ & 1.05 & $62 \pm 1.18^{\mathrm{T}}$ \\
\hline Lebar daun $(\mathrm{cm})$ & 0.10 & 0.03 & $0.07^{\mathrm{S}}$ & 0.53 & $70 \pm 2.65^{\mathrm{T}}$ \\
\hline Tinggi tanaman $(\mathrm{cm})$ & 64.05 & 60.89 & $3.16^{\mathrm{S}}$ & 3.55 & $5 \pm 0.03^{\mathrm{R}}$ \\
\hline Panjang batang $(\mathrm{cm})$ & 9.50 & 8.22 & $1.28^{\mathrm{S}}$ & 2.26 & $13 \pm 0.12^{\mathrm{R}}$ \\
\hline Diameter batang (mm) & 6.31 & 4.44 & $1.88^{\mathrm{S}}$ & 2.74 & $30 \pm 0.22^{\mathrm{S}}$ \\
\hline Lebar tajuk $(\mathrm{cm})$ & 118.75 & 57.44 & $61.31^{\mathrm{L}}$ & 15.66 & $52 \pm 0.07^{\mathrm{T}}$ \\
\hline Umur panen (hari) & 72.74 & 64.52 & $8.21^{\mathrm{L}}$ & 5.73 & $11 \pm 0.04^{\mathrm{R}}$ \\
\hline Panjang buah (cm) & 1.88 & 0.33 & $1.55^{\mathrm{s}}$ & 2.48 & $82 \pm 0.62^{\mathrm{T}}$ \\
\hline Diameter buah (mm) & 1.18 & 0.36 & $0.82^{\mathrm{S}}$ & 1.81 & $70 \pm 0.77^{\mathrm{T}}$ \\
\hline Tebal kulit buah (mm) & 0.05 & 0.06 & $0.00^{\mathrm{s}}$ & 0.00 & $0.00^{\mathrm{R}}$ \\
\hline Bobot per buah (g) & 2.33 & 0.59 & $1.74^{\mathrm{S}}$ & 2.64 & $75 \pm 0.57^{\mathrm{T}}$ \\
\hline Bobot buah total per tanaman (g) & $21,230.39$ & $27,403.88$ & $0.00^{\mathrm{s}}$ & 0.00 & $0.00^{\mathrm{R}}$ \\
\hline
\end{tabular}

Keterangan: $\mathrm{T}=$ Tinggi; $\mathrm{R}=$ Rendah $\mathrm{S}=$ Sempit $\mathrm{L}=$ Luas

lainnya memiliki korelasi negatif (Tabel 4). Nilai korelasi menunjukkan tingkat keeratan antar karakter kuantitatif tanpa menjelaskan hubungan kausalitas (Lelang, 2017). Menurut Chesaria et al. (2018), nilai korelasi yang bersifat positif menunjukkan adanya hubungan yang sejalan antar karakter sedangkan nilai korelasi negatif menunjukkan sebaliknya. Hasil studi Chesaria et al. (2018) sebelumnya menunjukkan bahwa karakter panjang buah, diameter buah, dan bobot per buah memiliki korelasi yang positif terhadap bobot buah per tanaman, artinya setiap kenaikan panjang, diameter, dan bobot per buah juga akan diikuti oleh kenaikan bobot buah per tanaman. Menurut Setiawan et al. (2019) karakter produksi merupakan karakter yang kompleks karena dipengaruhi oleh komponen pertumbuhan dan hasil. Karakter-karakter dengan nilai korelasi positif terhadap karakter produksi dapat digunakan dalam program pemuliaan tanaman untuk meningkatkan hasil melalui kegiatan seleksi (Usman et al., 2016).

Analisis korelasi hanya memperlihatkan seberapa erat hubungan antara karakter yang satu dengan karakter yang lain tetapi tidak mampu menunjukkan adanya hubungan kausalitas atau sebab akibat (Sa'diyah et al., 2020). Oleh karena itu diperlukan sidik lintas untuk menjelaskan hubungan sebab akibat tersebut. Pada sidik lintas, dapat diketahui pengaruh langsung maupun tidak langsung antara suatu karakter terhadap karakter lainnya. Pengaruh langsung menunjukkan pengaruh suatu karakter terhadap daya hasil tanpa melalui karakter lain sedangkan pengaruh tidak langsung menunjukkan pengaruh suatu karakter terhadap daya hasil melalui karakter lain (Putri et al., 2017).

Hasil sidik lintas menunjukkan bahwa karakter tebal kulit buah, bobot per buah, panjang batang, diameter batang, lebar tajuk, dan lebar daun memiliki nilai koefisien pengaruh langsung yang positif, sedangkan karakter diameter buah, umur berbunga, dan umur panen memiliki nilai koefisien pengaruh langsung yang negatif.. Lenka dan Mishra (1973) mengklasifikasikan nilai pengaruh sidik lintas menjadi lima kriteria, yaitu nilai 0.00-0.09 termasuk kriteria dapat diabaikan, nilai 0.10-0.19 termasuk rendah, nilai 0.20-0.29 termasuk sedang, nilai 0.30-0.99 termasuk tinggi. Karakter lebar tajuk memiliki nilai koefisien pengaruh langsung yang tinggi berdasarkan kriteria Lenka dan Mishra (1973) yaitu sebesar 0.359 dan pengaruh total sebesar 0.50 (Tabel 5), sehingga seleksi langsung untuk karakter produksi dapat dilakukan menggunakan karakter tersebut. Sementara itu karakter diameter batang memiliki nilai pengaruh langsung yang tergolong sedang menurut kriteria Lenka dan Mishra (1973), namun pengaruh total yang tinggi yaitu sebesar 0.391 (Tabel 5), sehingga karakter tersebut juga dapat digunakan sebagai kriteria seleksi untuk peningkatan hasil.

Nilai pengaruh sisa yang diperoleh dari sidik lintas pada penelitian ini sebesar 0.683, artinya sebesar $68.3 \%$ pengaruh langsung terhadap karakter produksi tidak berasal dari kedua belas karakter yang dianalisis melainkan berasal dari karakter lainnya yang tidak dapat dijelaskan pada model analisis ini. Menurut Kartina et al. (2016), nilai pengaruh sisa menunjukkan adanya pengaruh langsung yang masih belum terhitung pada karakter yang belum dimasukkan dalam analisis. Rohaeni dan Permadi (2012) menyatakan bahwa nilai pengaruh sisa yang semakin mendekati nol menunjukkan semakin efektif sidik lintas yang dilakukan dalam menjelaskan hubungan kausalitas dari nilai korelasi dan menjelaskan pengaruh langsung maupun tidak langsung dari karakter kuantitatif yang dianalisis. 


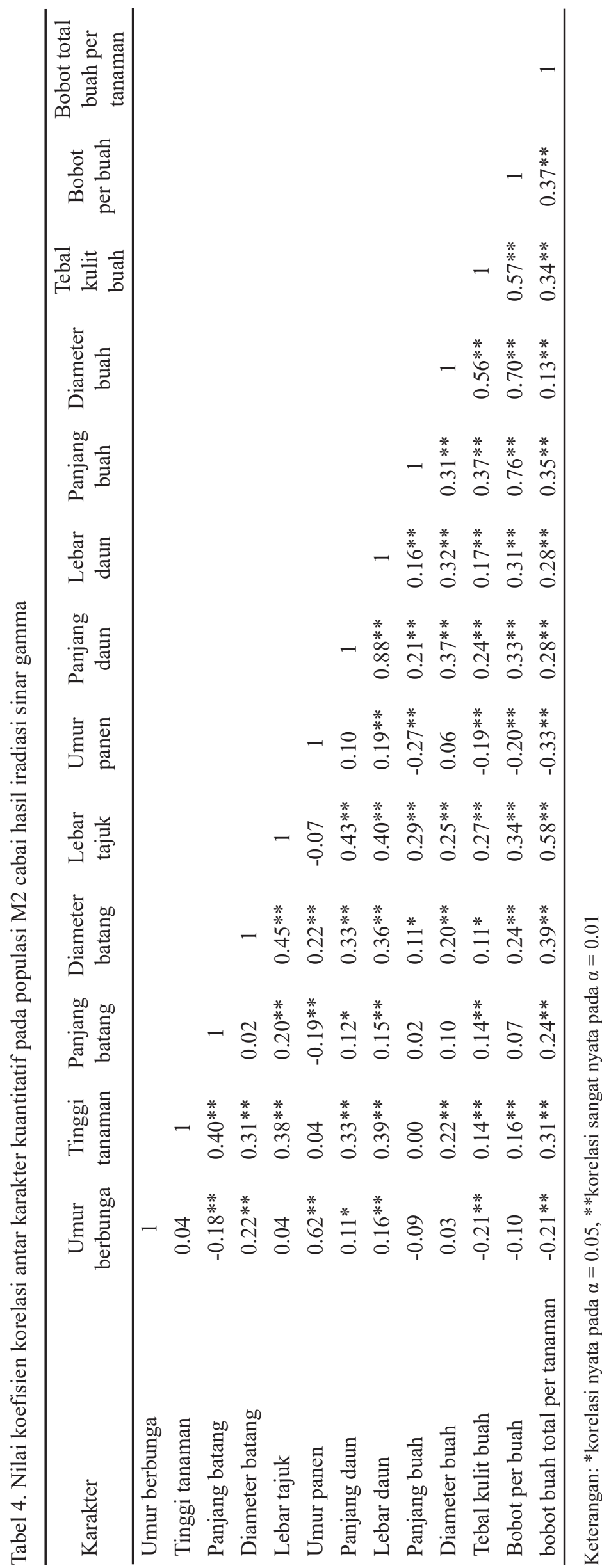

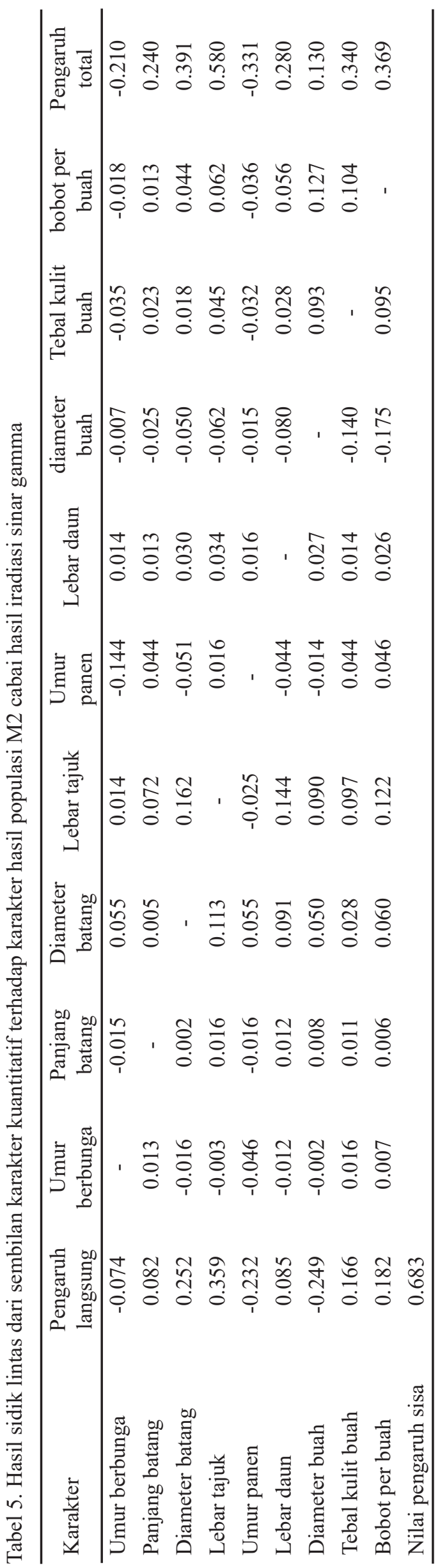




\section{KESIMPULAN}

Induksi mutasi melalui iradiasi sinar gamma pada dosis 450 Gy mampu meningkatkan keragaman genetik pada dua karakter kuantitatif yaitu lebar tajuk dan umur panen pada populasi M2 cabai. Karakter panjang buah, diameter buah, bobot per buah, panjang daun, lebar daun, dan lebar tajuk pada populasi M2 menunjukkan nilai heritabilitas arti luas yang tinggi. Sidik lintas menunjukkan terdapat dua karakter yang menunjukkan pengaruh langsung yang besar terhadap peningkatan hasil yaitu lebar tajuk dan diameter batang.

\section{UCAPAN TERIMA KASIH}

Penulis menyampaikan terima kasih kepada Badan Litbang Pertanianyang telahmembiayai penelitian ini melalui Beasiswa Tugas Belajar Badan Litbang Pertanian. Penulis juga menyampaikan terima kasih kepada Balai Penelitian Tanaman Sayuran (Balitsa) yang telah menyediakan materi genetik untuk kegiatan penelitian ini.

\section{DAFTAR PUSTAKA}

Adiyoga, W., Nurmalinda. 2012. Analisis konjoin preferensi konsumen terhadap atribut produk kentang, bawang merah, dan cabai merah. J. Hort. 22:292-302.

Andini, S.N., J. Kartahadimaja, M.F. Sari. 2021. Seleksi mutan generasi dua (M2) kedelai hitam terhadap produksi tinggi. J. Penelitian Pertanian Terapan 21:3239. Doi:https://doi.org/10.25181/jppt.v21i1.1950.

Asghar, M.J., S.S Mehdi. 2010. Selection indices for yield and quality traits of sweet corn. Pak. J. Bot. 42:775789.

[Balitbangtan] Badan Penelitian dan Pengembangan Pertanian. 2019. Deskripsi varietas Lingga. https:// www.litbang.pertanian.go.id/varietas/889/. Oktober 2021].

Chesaria, N., Sobir, M. Syukur. 2018. Analisis keragaan cabai rawit merah (Capsicum frutescens) lokal asal Kediri dan Jember. Bul. Agrohorti 6:388-396.

Ekaputra, E.G., F. Arlius, O.C. Chatib, F. Irsyad. 2018. Pengembangan klaster tanaman cabai di Kabupaten Agam Provinsi Sumatera Barat. J. Hilirisasi IPTEKS 1:99-108.

Gaswanto, R., M. Syukur, B.S. Purwoko, S.H. Hidayat. 2016. Induced mutation by gamma rays irradiation to increase chilli resistance to Begomovirus. Agrivita 38:24-32. Doi:http://dx.doi.org/10.17503/agrivita. v38i1.581.

Harsanti, L., Yulidar. 2019. Pertumbuhan varietas kedelai (Glycine $\max (\mathrm{L}$.) Merill) pada generasi M2 dengan teknik mutasi. J. Sains dan Teknologi Nuklir Indonesia 20:1-8. Doi:http://dx.doi.org/10.17146/ jstni.2019.1.1.4104.

Hartati, S., L. Darsana. 2015. Karakterisasi anggrek alam secara morfologi dalam rangka pelestarian plasma nutfah. J. Agron. Indonesia 43:133-139.

Herison, C., E. Surmaini, Rustikawati, Yulian. 2018. Morphological characterization of 10 chili pepper genotipes in low altitude land. Akta Agrosia 21:4754.

Indhirawati, R., A. Purwantoro, P. Basunanda. 2015. Karakterisasi morfologi dan molekuler jagung berondong stroberi dan kuning (Zea mays L. kelompok Everta). Vegetalika 4:102-114.

[IPGRI] International Plant Genetic Resources Institute. 1995. Descriptors for Capsicum (Capsicum spp.). International Plant Genetic Resources Institute (IPGRI), Rome, IT.

Kartina, N., B.P. Wibowo, Y. Widyastuti, I.A. Rumanti, Satoto. 2016. Korelasi dan sidik lintas karakter agronomi padi hibrida. J. Ilmu Pertanian Indonesia 21:76-83. Doi:10.18343/jipi.21.2.76.

Kusandriani, Y. 1996. Pembentukan Cabai Hibrida. Balai Penelitian Tanaman Sayuran, Bandung, Indonesia.

Lelang, M.A. 2017. Uji korelasi dan analisis lintas terhadap karakter komponen pertumbuhan dan karakter hasil tanaman tomat (Lycopersicum esculentum Mill.). Savana Cendana 2:33-35. Doi:https://doi. org/10.32938/sc.v2i02.90.

Lenka, D., B. Mishra. 1973. Path coefficient analysis of yield in rice varieties. Indian. J. Agric. Sci 43:376379.

Lothrop, J.E., R.E. Atkins, O.S. Smith. 1985. Variability for yield and yield components in IAPIR grain sorghum random mating population. I. Means, variance components and heritabilities. Crop Sci. 25:235240.

Nura, M. Syukur, N. Khumaida, Widodo. 2015. Radiosensitivitas dan heritabilitas ketahanan terhadap penyakit antraknosa pada tiga populasi cabai yang diinduksi iradiasi sinar gamma. J. Agron. Indonesia 43:201-206.

Ojua, E.O., N.E. Abu, J.O. Omeke, N.M. Eze, J.O. Okawnu, C.K. Chukwuma. 2019. Effect of gamma irradiation on fruits of three pepper varieties. Int. J. Sci. Technol 7:26-30. Doi:10.24940/theijst/2019/v7/i1/ST1901020 . 
Putri, F.D., Sobir, M. Syukur, A. Maharijaya. 2017. Pengembangan kriteria seleksi untuk perakitan terung (Solanum melongena L.) berdaya hasil tinggi. J. Agron. Indonesia 45:182-187. Doi:https://doi. org/10.24831/jai.v45i2.13077.

Rohaeni, W.R., K. Permadi. 2012. Analisis sidik lintas beberapa karakter komponen hasil terhadap daya hasil padi sawah pada aplikasi Agrisimba. Agrotrop 2:185-190.

Sa'diyah, N.M., A. Fitri, Rugayah, A. Karyanto. 2020. Korelasi dan analisis lintas antara percabangan dengan produksi cabai merah (Capsicum annuum L.) hasil iradiasi sinar gamma. J. Agrotek. Tropika 8:169-176.

Sari, W.P., Damanhuri, Respatijarti. 2014. Keragaman dan heritabilitas 10 genotip pada cabai besar (Capsicum annuum L.). J. Prod. Tan. 2:301-307.

Sarsu F., M.M. Spencer-Lopes, R. Sangwan, S. Penna. 2018. Specific techniques for increasing efficiency of mutation breeding. p 205-264. In M.M SpencerLopes, B.P. Forster, L. Jankuloski (Eds.). Manual on Mutation Breeding Third Edition. Roma (IT): Food and Agriculture Organization of the United Nations.

Setiawan, I.K., B. Waluyo, D. Saptadi. 2019. Uji daya hasil 6 genotip tanaman cabai besar (Capsicum annuum L.) di dataran tinggi. J. Prod. Tan. 7:2344-2351.
Stansfield, W.D. 1991. Schaum's Outline Series Theory and Problems of Genetics Third Edition. McGraw Hill Book Company, USA.

Sumilah, N.F. Devy, Hardiyanto. 2019. Karakterisasi karakter morfologi daun dan bunga varietas lokal ubi jalar (Ipomea batatas L.) Kabupaten Agam dan Solok, Provinsi Sumatra Barat. BPN 25:91-98.

Tomlekova, N., V. Spasova-Apostolova, I. Pantchev, F. Sarsu. 2021. Mutation associated with orange fruit color increases concentrations of Beta-Carotene in a sweet pepper variety (Capsicum annuum L.). Foods 10: 1225. Doi:https://doi.org/10.3390/foods10061225.

Usman, M.G., M.Y. Rafii, M.Y. Martini, Y. Oladosu, P. Kashiani. 2016. Genotypic character relationship and phenotypic path coefficient analysis in chili pepper genotypes grown under tropical condition. J. Sci. Food. Agric. 97:1164-1171.

Warid, N. Khumaida, A. Purwito, M. Syukur. 2017. Pengaruh iradiasi sinar gamma pada generasi pertama (M1) untuk mendapatkan genotipe unggul baru kedelai toleran kekeringan. Agrotrop 7:11-21.

Werdhiwati, P., S.H. Sutjahjo, D. Wirnas. 2020. Induksi mutasi sinar gamma dan seleksi tanaman okra merah untuk perbaikan daya hasil. J. Hort. Indonesia 11:7281. Doi:http://dx.doi.org/10.29244/jhi.11.1.72-81. 